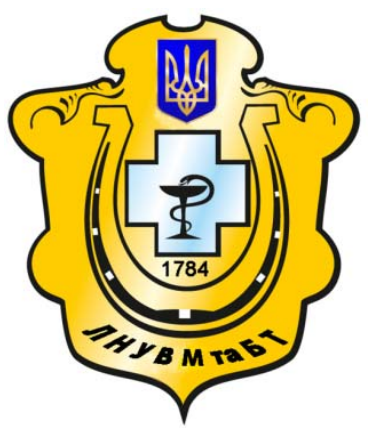

Науковий вісник Львівського національного університету ветеринарної медицини та біотехнологій імені С.3. Гжицького

Scientific Messenger of Lviv National University of Veterinary Medicine and Biotechnologies named after S.Z. Gzhytskyj

doi:10.15421/nvlvet6924

ISSN 2413-5550 print

ISSN 2518-1327 online

http://nvlvet.com.ua/

УДК 658.14/17

\title{
Роль факторингових операцій у сучасних фінансових розрахунках
}

\author{
Н.Б. Радух \\ nraduh@ukr.net

\begin{abstract}
Львівський національний університет ветеринарної медицини та біотехнологій імені С.З. Гжиџького,
\end{abstract} \\ вул. Пекарська, 50, м. Львів, 79010, Украӥна
}

У статті розкрито зміст факторингових операчій, їх роль та значення у забезпеченні ефективної виробничогосподарської і фінансової діяльності вітчизняних підприємств. Визначено, щяо найбільшу потребу у факторингових розрахунках мають малі та середні підприємства, котрі відчувають фінансові труднощі у зв'язку з несвоєчасним погаменням боргів дебіторами та обмеженістю можливих джерел кредитування. Роль факторингу полягає у зменшенні неплатежів, прискоренні товарообігу й створенні стабільної системи фінансового забезпечення виробничо-господарської діяльності підприємств. Проведено аналіз основних показників, щчо характеризують сучасний рівень використання факторингу. Виокремлено основні завдання факторингу для забезпечення ефективності фінансової, економічної та маркетингової діяльності. Розглянуто умови факторингу для сільськогосподарських підприємств, зокрема можливості та загрози. Основна увага акиентується на застосуванні факторингових розрахунків як інструменту активізаиії продажу сільськогосподарської продукиії та управління дебіторською заборгованістю. Однак висока ризикованість факторингу в порівнянні з іншими банківськими продуктами є суттєвою перешкодою для його повноиінного розвитку на національному ринку фінансових послуг. Невідповідне інформаційне забезпечення, незадовільний стан нормативно-правового регулювання, висока вартість послуг та кредитний ризик, складність у пошуку компанії-фактора стримує розвиток факторингових послуг в Україні. 3 а таких обставин особливо актуальною с проблема пошуку та впровадження передових технологій мінімізації ризиків факторингових операцій.

Ключові слова: факторинг, дебіторська заборгованість, фактор, ліквідність, валовий внутрішній продукт, грошові кошти, фінансові ресурси.

\section{Роль факторинговых операций в современных финансовых расчетах}

\author{
Н.Б. Радух \\ nraduh@ukr.net
}

Львовский национальный университет ветеринарной медищины и биотехнологий имени С.3. Гюицкого, ул. Пекарская, 50, г. Львов, 79010, Украина

В статье раскрыто содержание факторинговых операций, их роль и значение в обеспечении эффективной производственно-хозяйственной и финансовой деятельности отечественных предприятий. Проведен анализ основных показателей, которые характеризуют современный уровень использования факторинга. Выделены основные задания факторингу для обеспеченныя эффективности финансовой, экономической и маркетинговой деятельности. Рассмотрены условия факторинга для сельскохозяйственных предприятий, в частности возможности и угрозы. Основное внимание акиентируется на применении факторинговых расчетов как инструменту активизации продажи сельскохозяйственной продукции и управления дебиторской задолжснностью. Однако высокая рискованность факторинга по сравнению с другими банковскими продуктами являются существенным препятствием для его полноченного развития на национальном рынке финансовых услуг. Несоответствующее информационное обеспечение, неудовлетворительное состояние нормативно-правового регулирования, высокая стоимость услуг кредитный риск, сложность в поиске компании-фактора сдерживает развитие факторинговых услуг в Украине. При таких обстоятельствах особенно актуальна проблема поиска и внедрения передовых технологий минимизации рисков факторинговых операщий.

Citation:

Radukh, N.B. (2016). A role of faktoring operations is in modern financial arrangements. Scientific Messenger LNUVMBT named after S.Z. Gzhytskyj, 18, 2(69), 123-126. 
Ключевые слова: факторинг, дебиторская задолженность, фактор, ликвидность, валовой внутренний продукт, денежные средства, финансовые ресурсы.

\title{
A role of faktoring operations is in modern financial arrangements
}

\author{
N.B. Radukh \\ nraduh@ukr.net \\ Lviv national university of veterinary medicine and biotechnologies named after S. Gzhytskyj \\ Pekarska Str., 50, Lviv, 79010, Ukraine
}

In the article maintenance of faktoring operations, their role and value, is exposed in providing of effective production and financial activity of domestic enterprises. It was determined that the greatest need for factoring calculations are small and medium enterprises, which are experiencing financial difficulties due to delayed repayment of debts and debtors limited potential sources of financing. The role of factoring is to reduce payments, accelerating the turnover and the creation of a stable financial system providing industrial and economic activity. The analysis of basic indexes which characterize the modern level of the use of faktoring is conducted. Basic tasks faktoring are selected for well-to-do efficiency of financial, economic and marketing activity. The terms of faktoring are considered for agricultural enterprises, in particular possibilities and threats. Basic attention is accented on application of factoring calculations as to the instrument of activation of sale of agricultural produce and management an account receivable. However, the high risks of factoring compared to other banking products is a major obstacle to its full development in the national market of financial services. Inadequate provision of information, poor state legislation and regulation, high cost of services and the credit risk of the difficulty in finding factor holding back the development of factoring services in Ukraine. In such circumstances, the problem is particularly relevant for search and implementation of advanced technologies to minimize risks factoring operations.

Key words: faktoring, account receivable, factor, liquidity, gross domestic product, money, financial resources.

\section{Вступ}

Факторинг виступає одним із способів альтернативного фінансування підприємств, забезпечуючи трансформацію дебіторської заборгованості у грошові кошти і поповнення власних надходжень фінансових ресурсів. Найбільшу потребу у факторингових розрахунках мають малі та середні підприємства, котрі відчувають фінансові труднощі у зв'язку з несвоєчасним погашенням боргів дебіторами та обмеженістю можливих джерел кредитування. Роль факторингу полягає у зменшенні неплатежів, прискоренні товарообігу й створенні стабільної системи фінансового забезпечення виробничо-господарської діяльності підприємств.

Актуальність теми. Сучасний ринок факторингових послуг представляють лише деякі банківські установи, що мають низку спеціальних умов до потенційних клієнтів: переведення рахунків підприємства на обслуговування, максимальна кількість дебіторів не перевищує п'яти покупців, встановлюється мінімальна сума обслуговування не менше 50 тис. грн, може надаватися забезпечення у вигляді нерухомого майна. Недоліком факторингових послуг, що стримує зацікавленість потенційних учасників факторинговими операціями, є великий відсоток перевідступлення боргу, який сьогодні застосовують вітчизняні банки у тарифах за обслуговування. Новим клієнтам одержати факторингові послуги дуже складно і дорого, реальна ставка фінансування 28 - 35\% річних. У розвинених країнах вартість факторингу становить у середньому близько $1,5-2 \%$ від суми постачання.

Мета дослідження полягає у визначенні динаміки ринку факторингових послуг у сучасних умовах та аналізі можливостей і загроз факторингу при застосуванні у фінансових розрахунках суб'єктів господарювання.
Для досягнення поставленої мети визначено такі завдання:

- здійснити оцінку сучасного стану та умов використання факторингових операцій;

- визначити можливості та загрози факторингу у фінансових розрахунках підприємств;

- окреслити основні завдання факторингових послуг у забезпеченні ефективності виробничогосподарської діяльності підприємств малого і середнього бізнесу.

\section{Матеріал і методи досліджень}

У процесі дослідження використано такі наукові методи: абстрактно-логічний, зокрема його прийоми узагальнення, аналогії, аналізу та синтезу, індукції та дедукції (для формулювання теоретичних узагальнень результатів дослідження, формулювання висновків i пропозицій); економіко-статистичний, зокрема його прийоми: порівняння (для співставлення фактичних даних звітного року з даними попередніх періодів).

\section{Результати та їх обговорення}

Для сільськогосподарських підприємств застосування факторингу має незаперечні переваги, оскільки на факторингове обслуговування можуть бути прийняті поставки на невеликі суми та скорочення касових розривів, викликаних поставками на умовах відкритого рахунка. Факторингове обслуговування - найкоротший шлях до розв'язання проблеми, адже сутність факторингу відображена в тому, що після отримання документів про постачання продукції фактор після перевірки платоспроможності покупця, виплачує своєму клієнтові від $60 \%$ до $90 \%$ суми платежу за поставлену продукцію. Відсоток фінансування залежить від платіжної дисципліни дебітора, а 10 - 40\%, 
що залишилися, перераховуються постачальникові після отримання платежу від дебітора, за відрахуванням комісійної винагороди, яка, зазвичай, складається зі сплати за обслуговування і плати за фінансування, якщо воно надавалося.

В Україні розвиток ринку факторингових послуг можна оцінити за кількістю та вартість укладених договорів факторингу (табл. 1) [2, с. 5].
За 2012 - 2014 рр. у сільському господарстві спостерігалося зниження обсягів укладення договорів факторингу на 92,6\% (на 16,2 млн. грн) і вже у 2015 р. ситуація кардинально покращилася, а укладання договорів факторингу у галузі зросло майже у 22 рази $[2$, c. 7$]$

Динаміка показників факторингових послуг у 2012-2015 pp.

\begin{tabular}{|l|c|c|c|c|c|c|}
\hline \multirow{2}{*}{ Показник } & \multicolumn{3}{|c|}{ Рік } & \multicolumn{2}{c|}{$\begin{array}{c}\text { Темпи приросту } \\
(2015 / 2014)\end{array}$} \\
\cline { 2 - 7 } & 2012 & 2013 & 2014 & 2015 & абсолютний & $\%$ \\
\hline Вартість договорів факторингу, млн. грн & 4438,7 & 5231,8 & 9236,8 & 4994,6 & $-4242,2$ & $-45,93$ \\
\hline Кількість договорів факторингу, од & 5616 & 6436 & 4816 & 4723 & -93 & $-1,93$ \\
\hline
\end{tabular}

Позитивна практика застосування факторингу підтверджується показниками провідних країн. Розвиток факторингу в Сполучених Штатах Америки на сучасному етапі скерований на співпрацю 3 урядом 3 метою залучення малого та середнього бізнесу до факторингового ринку шляхом популяризації та підвищення рівня їх освіченості щодо можливостей факторингу. Обяг факторингових операцій США в 2014 р. збільшився на 2\% порівняно з 2013 р., і становив 100,1 млрд. дол. США, у Польщі - 33,5 млрд. євро, що у співвідношенні до ВВП становило 8,1\%. У Німеччині у 2014 р. обсяги послуг факторингу до- сягли 189,9 млрд. євро, що на 10,8\% більше, ніж у 2013 р., у Франції загальний обсяг дебіторської заборгованості, переданої факторинговим компаніям у 2014 р., досягнув понад 226 млрд. євро, що у співвідношенні до ВВП складає 10,6\% [3, 4]. В Україні обсяг факторингових операцій у співвідношенні до ВВП у 2015 р. становив $0,25 \%$.

Основним джерелом фінансування факторингу $є$ власні фінансові ресурси, частка залучених коштів не перевищує 10\%. У 2015 р. порівняно з 2014 р. обсяги фінансування знизились за всіма джерелами (табл. 2) $[2$, c. 5$]$.

Таблиия 2

Джерела фінансування факторингових операцій у 2012-2015 рр.

\begin{tabular}{|l|c|c|c|c|c|c|}
\hline \multirow{2}{*}{ Показники } & \multicolumn{3}{c|}{ Рік } & \multicolumn{2}{c|}{$\begin{array}{c}\text { Темпи приросту } \\
(2015 / 2014)\end{array}$} \\
\cline { 2 - 7 } & 2012 & 2013 & 2014 & 2015 & абсолютний & $\%$ \\
\hline Власні кошти, млн. грн & 8179,0 & 6183,9 & 15168,8 & 13780,2 & $-1388,6$ & $-9,15$ \\
\hline Позичкові кошти юридичних осіб, млн. грн & 1584,4 & 367,7 & 1279,7 & 1251,9 & $-27,8$ & $-2,17$ \\
\hline Банківські кредити, млн. грн & 1643,0 & 3338,9 & 4926,3 & 793,6 & $-4132,7$ & $-83,9$ \\
\hline Інші джерела, млн. грн & 296,4 & 149 & 2146,1 & 728,7 & $-1417,4$ & $-66,1$ \\
\hline Всього, млн. грн & 11702,8 & 10039,5 & 23525,7 & 16555,9 & $-6969,8$ & $-29,6$ \\
\hline
\end{tabular}

Застосування факторингових розрахунків може сприяти активізації продажу продукції сільськогосподарських підприємств та управлінню дебіторською заборгованістю, яка є досить вагомою для сільського господарства. У 2014 р. частка дебіторської заборгованості сільського, лісового та рибного господарства становила 7,71\% у загальній дебіторській заборгованості за всіма видами економічної діяльності, тоді як найбільшу частку дебіторської заборгованості визначено лише для промисловості $(30,3 \%)$ та оптової i роздрібної торгівлі $(29,3 \%)$ (табл. 3) [1, с. 56].
Постійне зростання обсягів дебіторської заборгованості в структурі активів підприємств зумовлює необхідність впровадження та поширення факторингових послуг. Однак висока ризикованість факторингу в порівнянні з іншими банківськими продуктами $\epsilon$ суттєвою перешкодою для його повноцінного розвитку на національному ринку фінансових послуг. За таких обставин особливо актуальною $\epsilon$ проблема пошуку та впровадження передових технологій мінімізації ризиків факторингових операцій.

Обсяги та структура оборотних активів сільського, лісового та рибного господарства України

\begin{tabular}{|c|c|c|c|c|c|c|c|}
\hline \multirow{2}{*}{ Показники } & \multicolumn{2}{|c|}{$2012 \mathrm{p}}$. & \multicolumn{2}{|c|}{$2013 \mathrm{p}}$. & \multicolumn{2}{|c|}{2014 p. } & \multirow{2}{*}{$\begin{array}{l}2014 \text { р. до } \\
2012 \text { р., \% }\end{array}$} \\
\hline & мЛн. грн & $\%$ & мЛн. грн & $\%$ & млн. грн & $\%$ & \\
\hline $\begin{array}{l}\text { Оборотні активи, } \\
\text { у т. ч.: }\end{array}$ & 174753 & 100,0 & 195021 & 100,0 & 267541 & 100,0 & 37,2 \\
\hline запаси & 60542,7 & 34,6 & 66754,2 & 34,2 & 84446,9 & 31,6 & $-2,7$ \\
\hline поточні біологічні активи & 12152,7 & 7,0 & 11873,7 & 6,1 & 12094,9 & 4,5 & $-1,6$ \\
\hline дебіторська заборгованість & 85340,5 & 48,8 & 98290,2 & 50,4 & 151461 & 56,6 & 6,2 \\
\hline грошові кошти & 9014 & 5,2 & 9885,4 & 5,1 & 9445,1 & 3,5 & $-1,5$ \\
\hline поточні фінансові інвестиції & 1538,5 & 0,9 & 1330,5 & 0,7 & 1565,3 & 0,6 & $-0,1$ \\
\hline інші оборотні активи & 4496,7 & 2,6 & 5024 & 2,6 & 6214,1 & 2,3 & $-0,3$ \\
\hline
\end{tabular}


Факторинг може забезпечити ефективність сільськогосподарського підприємства, збільшивши обсяги продажу продукції, прибутковості підприємства і конкурентоспроможності через механізм рефінансування банком дебіторської заборгованості клієнта. Перевагою факторингових розрахунків є швидкість процесу фінансування, відсутність обмежень у розмірі фінансування, досить тривалий період фінансування без укладання додаткових угод, можливість вільного оперування коштів та розподіл ризику неплатежу 3 фактором. Серед основних причин незначного використання факторингу є погане інформаційне забезпечення сільськогосподарських підприємств, незадовільний стан нормативно-правового регулювання, висока вартість послуг, складність у пошуку компанії-фактора, високий ціновий та кредитний ризики (рис.1).

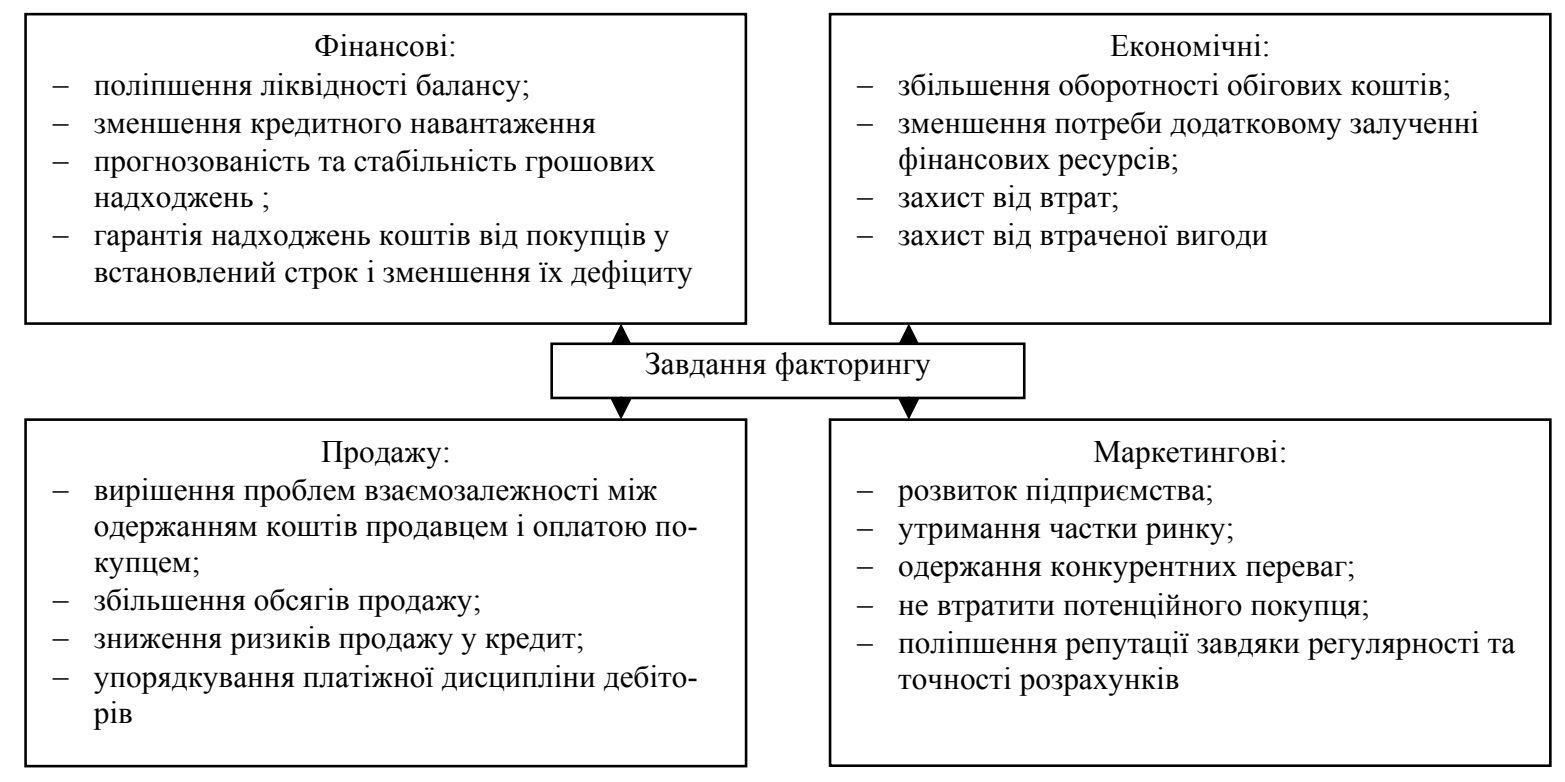

Рис. 1. Основні завдання факторингових розрахунків.

Світовий досвід розвитку факторингових послуг показує, що спеціалізовані факторингові компанії надають якісніший факторинговий сервіс, ніж банківські установи, тому для розвитку факторингового фінансування сільськогосподарських підприємств необхідно розвивати спеціалізовані факторингові компанії, діяльність та взаємовідносини яких з підприємствами регулювала б держава, враховуючи практику іноземних країн. У Франції здійснюється жорстке пруденційне регулювання факторингової діяльності, але це забезпечує дуже низький рівень ризику [4].

\section{Висновки}

Оцінка економічних показників факторингу в Україні дає підстави стверджувати про незначне використання факторингових розрахунків вітчизняними підприємствами. Невідповідне інформаційне забезпечення, незадовільний стан законодавчо-нормативного регулювання, висока вартість послуг та кредитний ризик, складність у пошуку компанії-фактора стримує розвиток факторингових послуг в Україні. Для багатьох іноземних підприємств, незалежно від розмірів, факторинг є гнучким фінансовим інструментом пришвидшення їх оборотності, що в кінцевому результаті сприяє зростанню національної економіки, тому держава повинна здійснюється жорстке пруден- ційне регулювання факторингової діяльності, використовуючи іноземний досвід.

Перспективи подальших досліджень. Актуальними продовжують залишатися проблеми інформаційного забезпечення та обізнаності керівного апарату вітчизняних підприємств перевагами факторингу та налагодження процесу його застосування у фінансових розрахунках. Важливим залишається розширення можливостей фінансових установ щодо надання якісних і надійних факторингових послуг.

\section{Бібліографічні посилання}

1. Activity of subjects of menage: stat collection. - Kyiv: Government service of statistics of Ukraine, 2015. $435 \mathrm{p}$.

2. Basic performance of financial companies indicators and leasing [Electronic resource]. - Access mode: http://nfp.gov.ua/content/stan-i-rozvitokfinansovih.html.

3. Factoring is in the countries of the EU [Electronic resource]. - Access mode: http://ukrfactor.com/factoring_EU/.

4. Factoring market of the USA [Electronic resource].Access mode: http://ukrfactor.com/factoring_USA/.

Стаття надійшла до редакиї 8.09.2016 